\title{
Sexual and asexual reproduction in Didemnum rodriguesi (Ascidiacea, Didemnidae)
}

\author{
Nicole F. Ritzmann ${ }^{1}$, Rosana M. da Rocha² \& James J. Roper ${ }^{3}$
}

1. Programa de Pós Graduação em Zoologia, Universidade Federal do Paraná, Caixa Postal 19020, 81531-980 Curitiba, Paraná, Brazil.

2. Departamento de Zoologia, Universidade Federal do Paraná, Caixa Postal 19020, 81531-980 Curitiba, Paraná, Brazil. (rmrocha@ufpr.br)

3. Programa de Pós Graduação em Ecologia e Conservação, Universidade Federal do Paraná, Caixa Postal 19034, 81531-980 Curitiba, Paraná, Brazil.

\begin{abstract}
Sexual and asexual reproduction and associated population dynamics were investigated in the colonial ascidian Didemnum rodriguesi Rocha \& Monniot, 1993 (Didemnidae) in southern Brazil. Investment in sexual (production of new individuals) and asexual (colony growth) reproduction was compared between seasons. Permanently marked quadrats were repeatedly photographed to measure changes in colonies. Eggs and larvae were counted monthly in collected colonies. This species alternates seasonally between sexual (summer) and asexual (winter) reproduction. In summer, colonies were smaller, brooded eggs and larvae and recruitment rates were greater, while in winter, colony size was larger and eggs and larvae were absent. There is a relationship between fecundity and colony area. Fragmentation and fusion of colonies were similar in summer and winter, as well as mortality. In conclusion, D. rodriguesi has a lifecycle usual for high latitude ascidians with a limited time length for sexual reproduction and alternate investment in sexual and asexual reproduction along the year.
\end{abstract}

KEYWORDS. Reproductive investment, sexual reproduction, fragmentation, tunicates.

RESUMO. Reprodução sexuada e assexuada em Didemnum rodriguesi (Ascidiacea, Didemnidae). Reprodução sexuada e assexuada, mortalidade e a dinâmica de fusões e fissões de colônias de Didemnum rodriguesi Rocha \& Monniot, 1993 foram investigados e comparados no sul do Brasil, no inverno e verão. Tais eventos foram analisados por fotografias de áreas permanentemente demarcadas e coletas mensais de colônias. Os resultados indicam que esta espécie alterna sazonalmente a reprodução sexuada (verão) e assexuada (inverno). Durante o verão as colônias são mais abundantes e menores, com ovos e larvas incubados e taxas de recrutamento maiores. No inverno há um menor número de colônias, porém de maior tamanho e inférteis. Existe uma relação entre fecundidade e tamanho da colônia. Não foram encontradas diferenças estatísticas no número de eventos de fragmentação e fusão entre o verão e inverno, bem como para mortalidade. Conclui-se que esta espécie tem um ciclo de vida típico de espécies de maiores latitudes, com tempo limitado para a reprodução sexuada e alternância no investimento entre reprodução sexuada e assexuada.

PALAVRAS-CHAVE. Investimento reprodutivo, reprodução sexuada, fragmentação, tunicados.

Reproductive strategies are important components of species life-history strategies and also influence persistence and geographical distribution. The production of gametes, especially eggs, is energetically expensive, and therefore strongly sensitive to selective pressures. The different ways by which energy is allocated to growth and reproduction in order to maximize fitness forms the basis of the differing life-history strategies that developed in marine invertebrates (LLODRA, 2002; TARJUELO \& TURON, 2004).

Modular organisms usually have indeterminate growth and are morphologically very plastic (KIM \& LASKER, 1998). Hence, their size and shape may vary throughout life and may change due to varying environmental conditions, as well as to biological interactions. Thus, size and modular organization varies between colonies and within colonies over time (PINEDAKRCH \& POORE, 2004).

Ascidians comprise marine invertebrate chordates with a wide variety of reproductive and life-history strategies (reviewed by BATES, 2005). Although hermaphroditic, many species are unable to fertilize their own eggs (LAMBERT, 2005). Sexual reproduction in colonial ascidians is through the production of male and female gametes, with internal fertilization that follows the release of sperm to the environment that is subsequently taken in by other individuals. In the Didemnidae, embryos are brooded within the tunic and as larvae are released to the sea. Larvae swim briefly until attachment to a suitable substrate when a new colony is initiated (MILLAR, 1971).

Asexual reproduction in colonial forms occurs in many ways: a colony may divide into smaller units (fragmentation or fission) or zooids may replicate within a colony through budding (colony growth). In a broad definition, there are three types of buds within ascidians: for colony growth (production of new zooids); to make new colonies; and to survive adverse environmental conditions (BATES, 2005). Colony growth has been studied in a number of ascidians, revealing complex patterns of growth and fission (BAK et al., 1981), influence of neighbors (STOCKER \& UNDERWOOD, 1991), or a strong seasonal component coupled with alternating sexual and asexual reproduction (GROSBERG, 1988; TURON \& BECERRO, 1992; Turon, 2005). These patterns suggest that demographic parameters of modular organisms may be a function of organism size rather than age (LiNACRE \& KeOUgh, 2003).

Some ascidian species fission very often with many small colonies being more or less continuously generated (BAK et al., 1981; RYLAND et al., 1984; STONER, 1989; 
Stocker, 1991; Turon, 2005). Fragmentation is also common in many other marine organisms, such as algae (WALtersa et al., 2002) and marine invertebrates (zoanthids, KARLSON, 1988; gorgonacean corals, LASKER, 1990; bryozoans, CociTo et al., 2001; Hughes et al., 2004) and is often important for recolonization after extreme environmental stress. In such circumstances, colony fragmentation enables the rapid growth and recovery of a genotype (OKA \& UsUI, 1944; RYLAND et al., 1984). In marine environments this process may be fundamental in the life history of an organism, in which it is a strategy of the species for reproduction (endogenous) or is a response to predation or other perturbations (exogenous), or both. Colony fragmentation may also be a dispersal mechanism, especially important for invasive species such as Didemnum sp.A (Bullard et al., 2007; VAlEnTine $e t$ al., 2007a).

Fusion of colonies is also an important life-cycle trait for species that have aggregate recruitment with near proximity of siblings (Botryllus schlosseri Pallas, 1766 Grosberg \& QuinN, 1986; Grosberg, 1987; Trididemnum solidum (Van Name, 1902) - DuYL et al., 1981). A possible explanation for the evolutionary maintenance of chimeras (mixed genotypes) is the enhancement of physiological tolerance (GROSBERG \& QUINN, 1986) or the promotion of heterozygozity by the resorption of the more homozygous partner (RINKEVICH \& WEISSMAN, 1992).

Modular growth, fragmentation and fission of colonies are part of the life-cycle of the encrusting ascidian Didemnum rodriguesi Rocha \& Monniot, 1993 which is relatively common in sublitoral rocky substrates of southeastern (RocHA \& BonNET, 2009) and southern Brazil (Rocha et al., 2005). Here we studied reproductive strategies of $D$. rodriguesi in terms of investment in sexual and asexual reproduction and their associations with mortality and fusion rates to test for the relative importance and consequences of each mode of reproduction. Specifically, we examined egg and larvae production and recruitment (sexual reproduction), colony size, growth and fragmentation (asexual reproduction), and their interactions and seasonality to better understand population dynamics of modular marine organisms.

\section{MATERIAL AND METHODS}

Arvoredo Island $\left(27^{\circ} 17^{\prime} 44^{\prime \prime} \mathrm{S}, 48^{\circ} 21^{\prime} 59^{\prime \prime} \mathrm{W}\right)$ in the state of Santa Catarina, in southern Brazil is a marine reserve at the confluence of the Brazilian current (warm water) and the Malvinas current (cold water). This study was carried out in Vital Bay on the island, where the $D$. rodriguesi, was studied at $6-8 \mathrm{~m}$ depth.

To measure sexual reproduction, 10 randomly selected colonies that varied in size were collected from different rocks each month from July 2003 to May 2004. Colonies were preserved in formalin $4 \%$. Spicules within the colonies were decalcified with $\mathrm{HCl} 3 \%$ to allow the observation and counting of eggs, incubated larvae and zooids, using a stereo dissecting microscope.

To measure colony dynamics (asexual reproduction) and recruitment (sexual reproduction), photographs were taken repeatedly of permanent quadrats $(12 \times 18 \mathrm{~cm}, \mathrm{n}=$
11 in summer, 9 in winter). Dynamics here were changes in size and abundance of colonies, as well as events of fusion or fission. Quadrats were permanently marked to insure photographs were taken of the same locations. Photographs were taken with a macro lens for Sea and Sea Motor Marine 35 MX-10 under water camera. Time interval between photographs varied from 7-18 days. Dates of photographs (all in the year 2004) were 29 January, 9 February, 14 February, 3 March, 13 March (summer) and 11 June, 19 June, 26 June (winter). Sample size was unequal due to inclement weather.

Sexual reproduction (as recruitment), asexual reproduction (colony fragmentation and growth), and other demographic events (attrition rates, mortality and colony fusions) were measured, counted or estimated from photographs. To analyze these processes over time, we followed approximately 10 easily recognizable colonies in each photograph. The number of recruits and mortalities were summed in each photograph by date of collection. Each new colony that appeared in a picture in a previously empty space was counted as a recruit. Mortality was counted when a colony disappeared from a picture. If a colony appeared in one picture, but was absent from the subsequent picture, it was counted as both a recruit and a death each on the appropriate date. Mortality rates were calculated as the number of events divided by the number of colonies and the time interval. Fusions and divisions (fragmentation) events were easily counted because of the shape change from one photograph to the next. Fusion and division rates were also estimated.

Growth of D. rodriguesi is complex because colonies may increase or decrease in area and fuse or fragment. Therefore, change in area may be positive (growth) or negative (attrition). Since density of zooids is relatively constant, growth implies the addition of zooids while attrition implies the loss of zooids. To estimate change in area (for both, growth and attrition) we used only clearly identifiable colonies that did not fragment or fuse during the time interval from one photograph to the next. Colony area was measured using Sigma Scan Pro 2.0, and change in area was estimated as the difference in area from one photograph to the next growth was when the difference was positive, attrition when the difference was negative.

Statistical Analysis. Student's $t$ - tests were used to compare colony size, egg and larvae production and mortality between seasons. Number of divisions, fusions and deaths of colonies were compared between seasons after controlling for the number of colonies and the time interval between observations by means of regression analysis. Data were tested to meet the assumptions of each analysis and when necessary the appropriate transformations were applied (see Results). All tests were considered significant when $\mathrm{p} \leq 0.05$.

\section{RESULTS}

Sexual reproduction. Reproduction (eggs and larvae) only occurred between November and May (June was not measured). Similarly, many more recruits were counted during summer $(n=230$, or a mean of 0.48 recruits 
per colony counted) than winter $(n=17$, or a mean of 0.04 recruits per colony counted, $t=4.81$, df $=15, \mathrm{p}<0.05$, Figs. 1, 2)

For analysis of colony area and fecundity, colonies were divided into four groups: with neither eggs nor larvae, with eggs but without larvae, with larvae but without eggs and with both, eggs and larvae. This comparison only included months in which eggs or larvae were found. Colonies increased in size with increasing investment in reproduction: non-sexually reproductive colonies were smallest, colonies with both eggs and larvae were largest, and reproductive status explained nearly $20 \%$ of the variation in colony size $\left(\mathrm{F}_{3,126}=10.7, \mathrm{r}^{2}=0.18\right.$, $\mathrm{p}<0.05$, Fig. 3). Due to few colonies with larvae only $(n=$ 7), this treatment was not different from the others, all of which were different from each other: colonies with eggs and larvae $\left(\right.$ mean $=80.0 \mathrm{~mm}^{2}$, se $\left.=1.15, \mathrm{n}=34\right)$, eggs only (mean $=50.4 \mathrm{~mm}^{2}$, se $=1.10, \mathrm{n}=22$ ) and non reproductive colonies $\left(\right.$ mean $=32.4 \mathrm{~mm}^{2}$, se $=1.10, \mathrm{n}=67$, Tukey $\mathrm{p}<$ 0.05 , Fig. 3 ) colonies. Similarly, both the number of eggs and the number of larvae and, consequently, the sum of the two, were positively correlated with colony area (Spearman's rho $>0.45$, all $\mathrm{p}<0.05$ ). Thus, there is a relationship between fecundity and colony area. Area of the smallest colony with eggs was $26 \mathrm{~mm}^{2}$.

Asexual reproduction. Colonies were larger in winter $\left(\right.$ mean $=55.2 \mathrm{~mm}^{2}$, se $=1.09$; summer mean $=14.7$ $\left.\mathrm{mm}^{2}, \mathrm{se}=1.08, t=11.3, \mathrm{df}=276, \mathrm{p}<0.05\right)$. Due to unequal

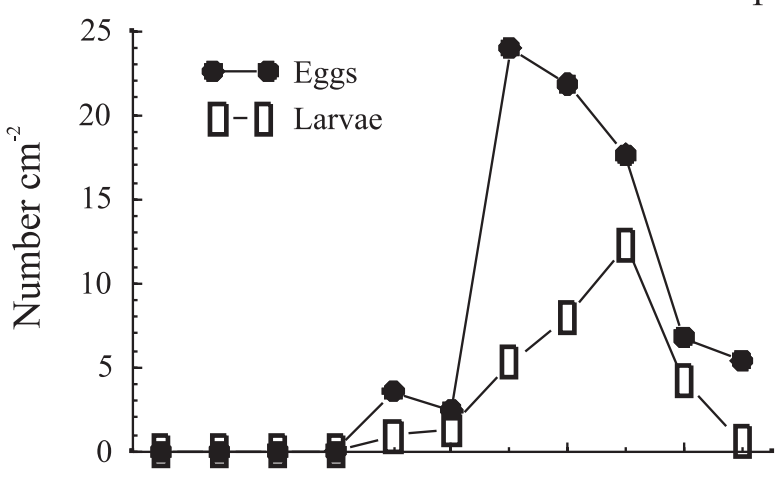

July Aug Sept Oct Nov Dec Jan Feb Mar Apr May

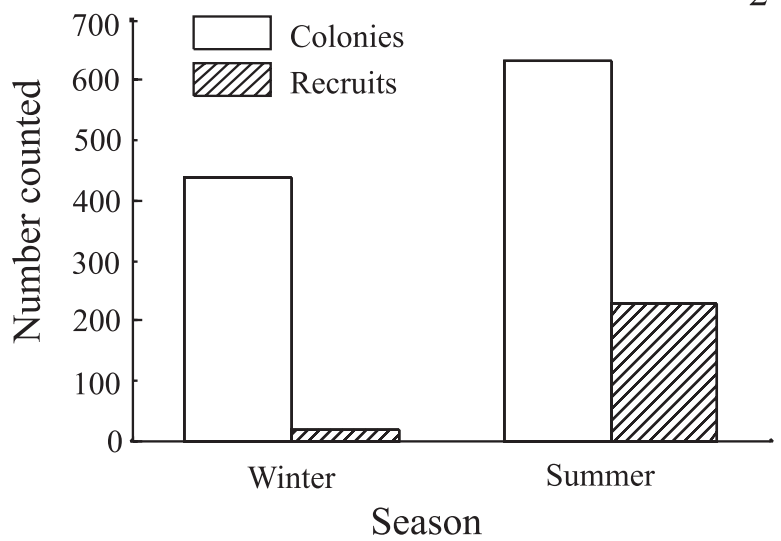

Figs. 1, 2. Two measures of sexual reproduction, egg and larvae of the Didemnum rodriguesi Rocha \& Monniot, 1993: 1, production; 2, recruitment. Egg and larvae production are counts controlling for colony area and adjusted to $1 \mathrm{~cm}^{2}$.

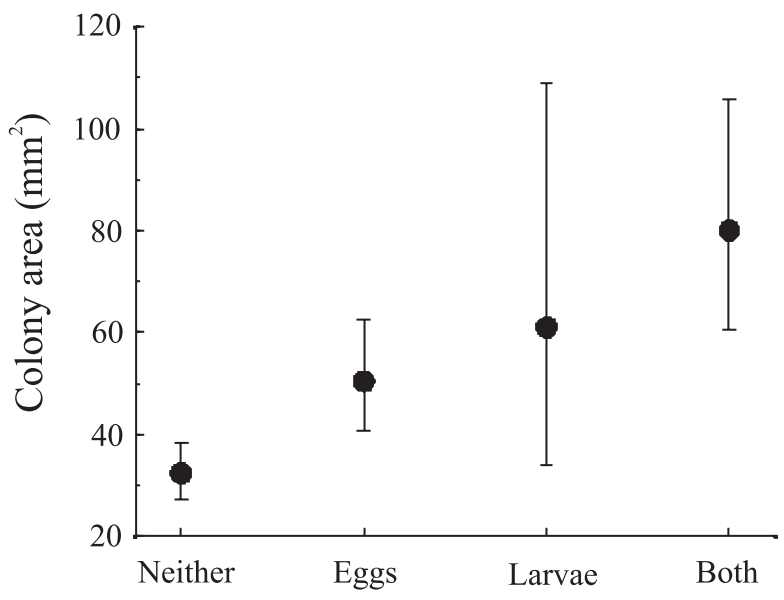

Fig. 3. Relationship between reproductive status and colony size of the Didemnum rodriguesi Rocha \& Monniot, 1993. Colonies with both larvae and eggs tend to be largest $\left(\mathrm{F}_{3,126}=10.7, \mathrm{r}^{2}=18, \mathrm{p}<\right.$ 0.05). Data were log transformed for analyses, but converted to the original scale for illustration. Three of the four treatments (neither, eggs, eggs and larvae) were all different (Tukey, p < 0.05) in the predicted direction.

sample size, a random sample of 139 of the summer measurements was taken for this comparison.

Comparisons of growth and attrition rates between summer and winter required that we controlled for time interval between photos as well as original area of the colony. This was accomplished through multiple regression from which residuals were taken to compare growth rates between seasons. Thus, the growth rate (area of growth per day per original colony area) was greater in winter $\left(0.029 \mathrm{~mm}^{2}\right.$ day $\left.^{-1} \mathrm{~mm}^{-2}\right)$ than summer $(0.021$ $\mathrm{mm}^{2}$ day $\left.^{-1} \mathrm{~mm}^{-2}, t=3.03, \mathrm{df}=463, \mathrm{p}<0.05\right)$. Attrition rates were similar between summer and winter $(t=0.56, \mathrm{df}=$ $302, \mathrm{p}>0.20)$. In summer, attrition rates $\left(0.027 \mathrm{~mm}^{2} \mathrm{day}^{-1}\right.$ $\left.\mathrm{mm}^{-2}\right)$ were greater than growth rates $\left(0.021 \mathrm{~mm}^{2}\right.$ day $^{-1}$ $\mathrm{mm}^{-2}, t$ for unequal variances $\left.=2.49, \mathrm{df}=571, \mathrm{p}<0.05\right)$. In winter growth and attrition rates were similar $\left(0.024 \mathrm{~mm}^{2}\right.$ day $^{-1} \mathrm{~mm}^{-2}, t=0.92, \mathrm{df}=194, \mathrm{p}>0.2$ ).

Zooid density was independent of colony area $(\mathrm{r}=$ $-0.13, \mathrm{df}=74, \mathrm{p}>0.2$ ) and therefore more or less constant. Hence, the number of zooids was correlated with colony area $(\mathrm{r}=0.89, \mathrm{df}=74, \mathrm{p}<0.05)$. Zooid density was also independent of season $(t=0.13, \mathrm{df}=77, \mathrm{p}>0.02)$. The number of fusions, divisions and colony death were independent of season (all p > 0.10).

\section{DISCUSSION}

Didemnum rodriguesi alternates seasonally between mostly asexual reproduction in winter and sexual reproduction in summer. Fewer and larger colonies are found in the winter. Growth rate is somewhat greater and is combined with larger colony size in winter, for greater absolute colony growth during this period. There is a positive correlation between the total number of zooids and colony area and this means that the increase in colony size includes zooid replication (asexual reproduction). Further, from July 2003 until October 2003 (winter and spring) neither eggs nor larvae were found within colonies and very few recruits were seen in the marked quadrats. 
Other species of colonial ascidians also alternate sexual and asexual reproduction (GoTELLI, 1987; DAVIS, 1989a; Durante \& SEBENS, 1994) and this tendency of the lifecycle is frequently associated with the geographic distribution of the colonies. Temperature is one of the most important physical factors controlling the life cycle of marine organisms (BHAUD et al.,1995) and apparently determines whether sexual reproduction occurs year round or only in warmer months (MillaR, 1971). Changes in water temperatures have been shown to affect gametogenesis and embryonic development. For example, there is a positive correlation between water temperature and larval release for the colonial ascidian Podoclavella moluccensis Sluiter, 1904 (DAVIS, 1989b; BINGHAM, 1997). A trend of increased asexual growth in colder temperatures was also found for five species of colonial ascidians from the northwestern Mediterranean (TURON \& BECERro, 1992). Also, the invasive Didemnum sp. subjected to experimental changes in temperature showed a weak but significant negative correlation between temperature and growth rate (MCCARTHY et al., 2007).

While growth was greater during winter, attrition is similar between seasons. Zooid regression and subsequent decrease in colony size is common in ascidians, especially in didemnids. Polysyncraton lacazei Giard, 1872, for instance, ceases to feed when it resorbs the branchial portion of the zooids and during zooid budding. This process is interpreted as rejuvenation that may extend the life span of the zooids (TURON, 1992). Degeneration also occurs spontaneously in colonies of Trididemnum solidum, when parts of the colony become covered with a mucus layer and subsequently disintegrate (BAK et al., 1981).

Attrition was greater than growth rate during the summer, but approximately equal to growth rate in winter, when growth rate was also greatest. These suggest that there may be a cost to sexual reproduction that occurs primarily during the summer. If so, this implies that both replication and survival of zooids decline while colonies are involved in sexual reproduction. The exact mechanism of this process merits further study.

Another form of asexual reproduction, colony fragmentation, was similar in summer and winter in $D$. rodriguesi. Fragmentation is a common reproductive strategy in cnidarians and up to $94 \%$ of some populations of plexaurid gorgonacea develop after fragmentation (LASKER, 1990). Fragmentation of colonial organisms may be a mechanism to increase genotype growth rates (KARLSON, 1988; StONER, 1989). Perhaps colonies that arise through fragmentation temporarily avoid the stages of sexual reproduction during which attrition rates are greater and thereby increase life span of each resulting fragment. In another congeneric didemnid, ability to fragment contributes to its competitiveness and its potential as a threat to benthic marine habitats and aquaculture in the northwestern Atlantic (VALENTINE $e t$ al., 2007b). Also, when an individual colony dies after fragmentation, its potentially immortal genotype may survive in other colonies (BAK et al., 1981). Predation may be an important cause of fragmentation. Fish, especially Diplodus argentus Valencienes, 1830 (Sparidae) were frequently observed foraging on the substrates that also supported $D$. rodriguesi. While observing fish actually consuming ascidians is difficult, colonies were seen drifting near the substrate while fish foraged. Also predation is probably often incomplete and parts of the colony may remain in the original location. Thus, colonies that survive partial predation may then grow and continue to reproduce both sexually and asexually.

The aggregate distribution pattern of $D$. rodriguesi may result from larvae limited dispersal (GROSBERG, 1987) or from extensive fragmentation in which fragments remain in place. Both mechanisms result in genetically related neighboring colonies and consequently fusion is more likely. The maintenance of fusion in the life history of didemnid and botryllid ascidians suggests that benefits accrue and surpass the costs of cell parasitism or zooid resorption associated with fusion (RINKEVICH \& WeIsManN, 1992). Fusions of colonies of D. rodriguesi were constant throughout the year. Fusion results in rapid changes in colony size. Fusion of genetically identical colonies of Trididemum solidum rapidly produced large colonies (DuYL et al., 1981), which may permit more rapid reproduction if a minimum colony size is necessary to initiate reproduction. Fusion may also reduce the probability of predation. For example, larger zoantid colonies have greater survival rates, competitive ability and reproductive success (KARLSON, 1988, but see RINKEVICH \& WEISSMAN, 1992). An inverse correlation between colony size and predation occurs in at least two species of colonial ascidians (TURON \& BECERRO, 1992). Finally, fusion may increase the possibility of outcrossing during sexual reproduction.

Apparently, a minimum size for sexual reproduction occurs in D. rodriguesi. While smaller colonies were counted and followed, $\sim 25 \mathrm{~mm}^{2}$ was the smallest colony with eggs and larvae. Many organisms show a positive correlation between fecundity and body size, such as the tunicate Botryllus schlosseri (HARVELL \& GROSBERG, 1988). As shown here, colony size increases with sexual reproduction. Therefore, two possibilities exist to explain small reproductive colonies. Either small sexually reproductive colonies are in good conditions for growth, or they are fragments of larger, already reproductive, colonies. Regardless, the minimum size at sexual reproduction suggests that there is a trade off between growth and reproduction and below some size, growth is most important. To test these hypotheses will require finer resolution of colony dynamics on the time scale of days instead of weeks.

In conclusion, the life cycle of $D$. rodriguesi alternates between sexual reproduction in the summer and growth and survival in the winter. Other forms of asexual reproduction (colony division, zooid budding) may occur throughout the year. This complex of growth, survival, sexual and asexual reproduction, fragmentation and fusion generates complex population dynamics. Understanding these dynamics is fundamental to understand patterns of abundance and distribution as well as current concerns of invasive potential of colonial species. We recommend further study at two scales. First, fine-tuned resolution of the process of survival, fragmentation, fusion and reproduction will require more frequent observations, since these processes may occur very rapidly. Second, genetic studies, such as phylogeographical studies on local and regional scales will help illuminate the consequences for population dynamics of these complex processes. 
Acknowledgements. We thank Seadivers Dive Center for the logistical support with dive operations. CAPES foundation gave a research grant to NR and CNPq to RMR. This is contribution 1713 of the Zoology Department, UFPR.

\section{REFERENCES}

BaK, R. P. M.; Sybesma, J. \& Duyl, F. C. 1981. The ecology of the tropical compound ascidian Trididemnum solidum. II. Abundance, growth and survival. Marine Ecology Progress Series 6:43-52.

BAtes, R. W. 2005. Environmental factors affecting reproduction and development in ascidians and other protochordates. Canadian Journal of Zoology 83:51-61.

Bhaud, M.; Cha, J. H.; Duchêne, J. C. \& Nozias, C. 1995. Influence of temperature on the marine fauna: what can be expected from a climatic change. Journal of Thermal Biology 20:91-104.

BINGHAM, B. L. 1997. Light cycles and gametogenesis in three temperate ascidian species. Invertebrate Biology 116:61-70.

Bullard, S. G.; Lambert, G.; Carman, M. R.; Byrnes, J.; Whitlach, R. B.; Ruiz, G.; Miller, R. J.; Harris, L.; Valentine, P. C.; Collie, J. S.; Pederson, J.; McNaught, D. C.; Cohen, A. N.; Asch, R. G.; Dikstra, J. \& Heinonen, K. 2007. The colonial ascidian Didemnum sp. A: Current distribution, basic biology and potential threat to marine communities of the northeast and west coasts of North America. Journal of Experimental Marine Biology and Ecology 342:99-108.

Cocito, S.; Sgorbini, S. \& Ferdeghini, F. 2001. Seasonal and interannual growth of a bryozoan bioconstructor. Archivio di Oceanografia e Limnologia 22:155-158.

Davis, A. R. 1989a. Contrasting population dynamics and life histories in two populations of the colonial subtidal ascidian Podoclavella moluccensis. Marine Ecology Progress Series 51:107-119.

1989b. Temperature correlates with the daily release of larvae and their settlement in a temperate Australian ascidian. In: Ryland, J. S. \& Tyler, P. A. eds. Reproduction, Genetics and Distribution of Marine Organisms (23rd European Marine Biology Symposium) Olsen \& Olsen. Fredensborg, Denmark. 23:61-65.

Durante, K. M. \& Sebens, K. P. 1994. Reproductive ecology of the ascidians Molgula citrina Alder \& Hancook, 1848 and Aplidium glabrum (Verril, 1871) from the Gulf of Maine, U.S.A. Ophelia 39:1-21

Duyl, F. C.; BaK, R. P. M. \& Sybesma, J. 1981. The ecology of the tropical compound ascidian Trididemnum solidum. I Reproductive strategy and larval behavior. Marine Ecology Progress Series 6:35-42.

Gotelli, N. J. 1987. Spatial and temporal patterns of reproduction, larval settlement, and recruitment of the compound ascidian Aplidium stellatum. Marine Biology 94:45-51.

GrosberG, R. K. 1987 Limited dispersal and proximity dependent mating success in the colonial ascidian Botryllus schlosseri. Evolution 41:372-384

1988. Life-history variation within a population of the colonial ascidian Botryllus schlosseri. 1. The genetic and environmental control of seasonal variation. Evolution 42:900-920.

Grosberg, R. K. \& Quinn, J. F. 1986. The genetic control and consequences of kin recognition by the larvae of a colonial marine invertebrate. Nature 322:456-459.

Harvell, C. D. \& Grosberg, R. K. 1988. The timing of sexual maturity in clonal animals. Ecology 69:1855-1864.

Hughes, N. R.; Manriquez, P. H.; Morley, S.; Craig, S. F. \& Bishop, J. D. D. 2004. Kin or self-recognition? Colonial fusibility of the bryozoan Celleporella hyalina. Evolution and Development 6:431-437.

Karlson, R. H. 1988. Size-dependent growth in two zoanthid species: a contrast in clonal strategies. Ecology 69:12191232.

Kim, K. \& LASKeR, H. 1998. Allometry of resource capture in colonial cnidarians and constraints on modular growth. Functional Ecology 12:646-654.

Lambert, C. C. 2005. Historical introduction, overview, and reproductive biology of the protochordates. Canadian Journal of Zoology 8:1-7.

LASKER, H. R. 1990. Clonal propagation and population dynamics of a gorgonian coral. Ecology 71:1578-1589.

Linacre, N. A. \& Keough, M. J. 2003. Demographic effects of fragmentation history in modular organisms illustrated using the bryozoan Mucropetraliella elleri (MacGillivray). Ecological Modelling 170:61-71

Llodra, E. R. 2002. Fecundity and life-history strategies in marine invertebrates. Advances in Marine Biology 43:88-170.

McCarthy, A.; Osman, R. W. \& Whitlach, R. B. 2007. Effects of temperature on growth rates of colonial ascidians: A comparison of Didemnum sp. to Botryllus schlosseri and Botrylloides violaceus. Journal of Experimental Marine Biology and Ecology 342:172-174.

Millar, R. H. 1971. The biology of ascidians. Advances in Marine Biology 9:1-100.

Ока, H. \& Usui, M. 1944. On the growth and propagation of the colonies in Polycitor mutabilis (Ascidiae Compositae) Science Reports: Tokyo Bunrika Daigaku, ser. b 7:23-53.

Pineda-Krch, M. \& Poore, A. G. B. 2004. Spatial interactions within modular organisms: genetic heterogeneity and organism fitness. Theoretical Population Biology 66:25-36.

Rinkevich, B. \& Weissman, I. L. 1992. Chimeras vs genetically homogeneous individuals: potential fitness costs and benefits. Oikos 63:119-24.

Rocha, R. M. \& Bonnet, N. Y. K. 2009 Ascídias (Tunicata, Ascidiacea) introduzidas no Arquipélago de Alcatrazes, São Paulo, Brasil. Iheringia, Série Zoologia, 99(1):27-35.

Rocha, R. M.; Moreno, T. R. \& Metri, R. 2005. Ascídias da Reserva Biológica Marinha do Arvoredo, SC. Revista Brasileira de Zoologia 22(2):461-476

Ryland, J. S.; Wigley, R. A. \& Muinead, A. 1984. Ecology and colonial dynamics of some Pacific reef flat Didemnidae (Ascidiacea). Zoological Journal of the Linnean Society 80:261-182

StOCKeR, L. J. 1991. Effects of size and shape of colony on rates of fission, fusion, growth and mortality in a subtidal invertebrate. Journal of Experimental Marine Biology and Ecology 149:161-175.

Stocker, L. J. \& Underwood, A. J. 1991. The relationship between the presence of neighbors and rates of sexual and asexual reproduction in a colonial invertebrate. Journal of Experimental Marine Biology and Ecology 149:191-205.

Stoner, D. S. 1989. Fragmentation: a mechanism for the stimulation of the genet growth rates in an encrusting colonial ascidian. Bulletin of Marine Sciences 45:277-287.

TARJuelo, I. \& TuRON, X. 2004. Resource allocation in ascidians: reproductive investment vs. other life-history traits. Invertebrate Biology 123:168-180.

Turon, X. 1992. Periods of non-feeding in Polysyncraton lacaze (Ascidiacea: Didemnidae): a rejuvenative process? Marine Biology 112:647-655.

2005. A new mode of colony multiplication by modified budding in the ascidian Clavelina gemmae n.sp. (Clavelinidae). Invertebrate Biology 124:273-283.

Turon, X. \& Becerro, M. A. 1992. Growth and survival of several ascidian species from the north western Mediterranean. Marine Ecology Progress Series 82:235-247.

Valentine, P. C.; Carman, M. R.; Blackwood, D. S. \& Heffron, E. J. 2007a. Ecological observations on the colonial ascidian Didemnum sp. in a New England tide pool habitat. Journal of Experimental Marine Biology and Ecology 342:109-121.

Valentine, P. C.; Collie, J. S.; Reid, R. N.; Asch, R. G.; Guida, V. G \& BlackwOOD D. S. 2007b. The occurrence of the colonial ascidian Didemnum sp. on Georges Bank gravel habitat Ecological observations and potential effects on groundfish and scallop fisheries. Journal of Experimental Marine Biology and Ecology 342:179-181

Waltersa, L. J.; Smith, C. M.; Coyerc, J. A. \& Hunterd, C. L. 2002. Asexual propagation in the coral reef macroalga Halimeda (Chlorophyta, Bryopsidales): production, dispersal and attachment of small fragments. Journal of Experimental Marine Biology and Ecology 278:47-65. 